\title{
TERIKE HAAPOJA
}

\section{TOISTENPUOLUE}

Yhteiskunnassamme elää miljoonia oikeudettomia. Oikeudettomat huolehtivat taloutemme perustarpeista: jätehuollosta, ruoantuotannosta, hapen ja hiilidioksidin kierrosta, vesivarojen kierrätyksestä ja raaka-aineiden tuottamisesta teollisuuden tarpeisiin. Oikeudettomia on yhteiskuntamme joka sektorilla taiteesta tieteeseen ja maataloudesta urheiluun, ja heitä on kaikissa yhteiskuntamme lajistoissa.

Oikeudettomilla tarkoitetaan kaikkia niitä, joilla ei ole lakiin kirjattuja perusoikeuksia eikä pääsyä poliittiseen päätöksentekoon esimerkiksi äänestämällä. Toisten Puolue on utopia poliittisesta puolueesta, joka antaa äänensä oikeudettomille.

\section{TEE TOISTEN POLITIIKASTA TODELLISUUTTA - ANNA ÄÄNESI TOISTEN PUOLESTA!}

www.toistenpuolue.fi

Terike Haapoja (s. 1974) valmistui kuvataideakatemiasta taiteen maisteriksi vuonna 2006 ja oli tätä ennen suorittanut teatterikorkeakoulussa esitystaiteen ja -teorian tutkinnon sekä opiskellut ääni- ja valaistustekniikkaa. Lisäksi hän on suorittanut opintoja Berliinissä ja Krakovassa. Haapojan ensimmäinen yksityisnäyttely Krakovassa 1999 käsitti maalauksia, mutta 2000-luvun projektinsa hän on toteuttanut installaatioina, joissa hän on hyödyntänyt monipuolisesti elektronisia kuvien tuottamisen ja käsittelyn menetelmiä. Kuvankäsittelytekniikat ovat monissa hänen töissään kietoutuneet yhteen orgaanisten muutos- ja kasvuprosessien kanssa. Hyvän osoituksen tästä työskentelytyylistä tarjosi näyttely "Closed Circuit - Open Duration" (Forum Box, Helsinki, 2008).

Haapoja on tutkinut nykyyhteiskunnan ja -kulttuurin suhdetta luonnon olioihin ja prosesseihin. Hänen työnsä koettelevat kykyämme ymmärtää luonto jonakin muuna kuin itsellemme ulkopuolisina näkyminä tai olioina. Sen sijaan huomion kohteeksi nousevat orgaaniset prosessit ja niiden jatkuva muuntuminen lähiympäristössämme. Haapojan kotisivulla (http://www.terikehaapoja. net/) on nähtävissä kooste sekä hänen aiemmista että valmisteilla olevista projekteistaan.

Haapojan viimeisin esillä ollut projekti on Toisten Puolue. Projekti laajentaa uudelle alueelle Haapojan näkemystä, että luonnon prosessit ovat elimellinen ja sisäistynyt osa inhimillisen toimeentulon perustaa. Osana projektiaan Haapoja on käynnistänyt kannatajakorttien keruun Toisten Puolue ry:n liittämiseksi puoluerekisteriin. Sen etenemistä voi seurata sivustolla http:// www.toistenpuolue.fi/.

Toisten Puolue ei ole hetkellinen provokatiivinen ele. Projektin tavoite on kehittää konkreettista sisältöä utopialle, että "luonnon ja eläinten intressit olisivat lainsäädännön ja poliittisen päätöksenteon keskiössä”. Taideprojektin avulla tällaisen tavoitteen tueksi on mahdollista käynnistää monipuolista oikeudellista, poliittista ja filosofista pohdintaa. 